\title{
Governing Urban Food Systems in the Long Run: Comparing Best Practices in Sustainable Food Procurement Regulations
}

\author{
Journal Article \\ Author(s): \\ Fesenfeld, Lukas \\ Publication date: \\ 2016
}

Permanent link:

https://doi.org/10.3929/ethz-a-010810909

Rights / license:

Creative Commons Attribution 3.0 Unported

Originally published in:

GAIA - Ecological Perspectives for Science and Society 25(4), https://doi.org/10.14512/gaia.25.4.8 


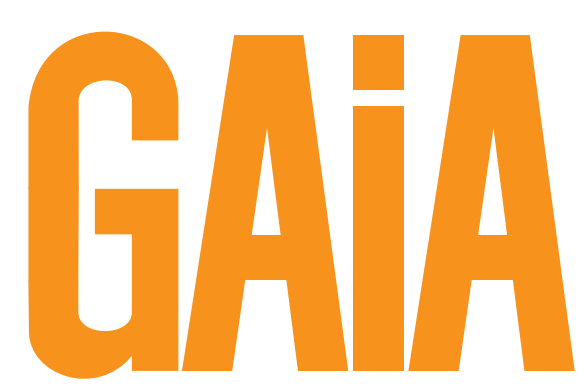

\section{$4 \mid 2016 \begin{aligned} & \text { ECOLOGICAL PERSPECTIVES FOR SCIENCE AND SOCIETY } \\ & \text { ÖKOLOGISCHE PERSPEKTIVEN FÜR WISSENSCHAFT UND GESELLSCHAFT }\end{aligned}$}

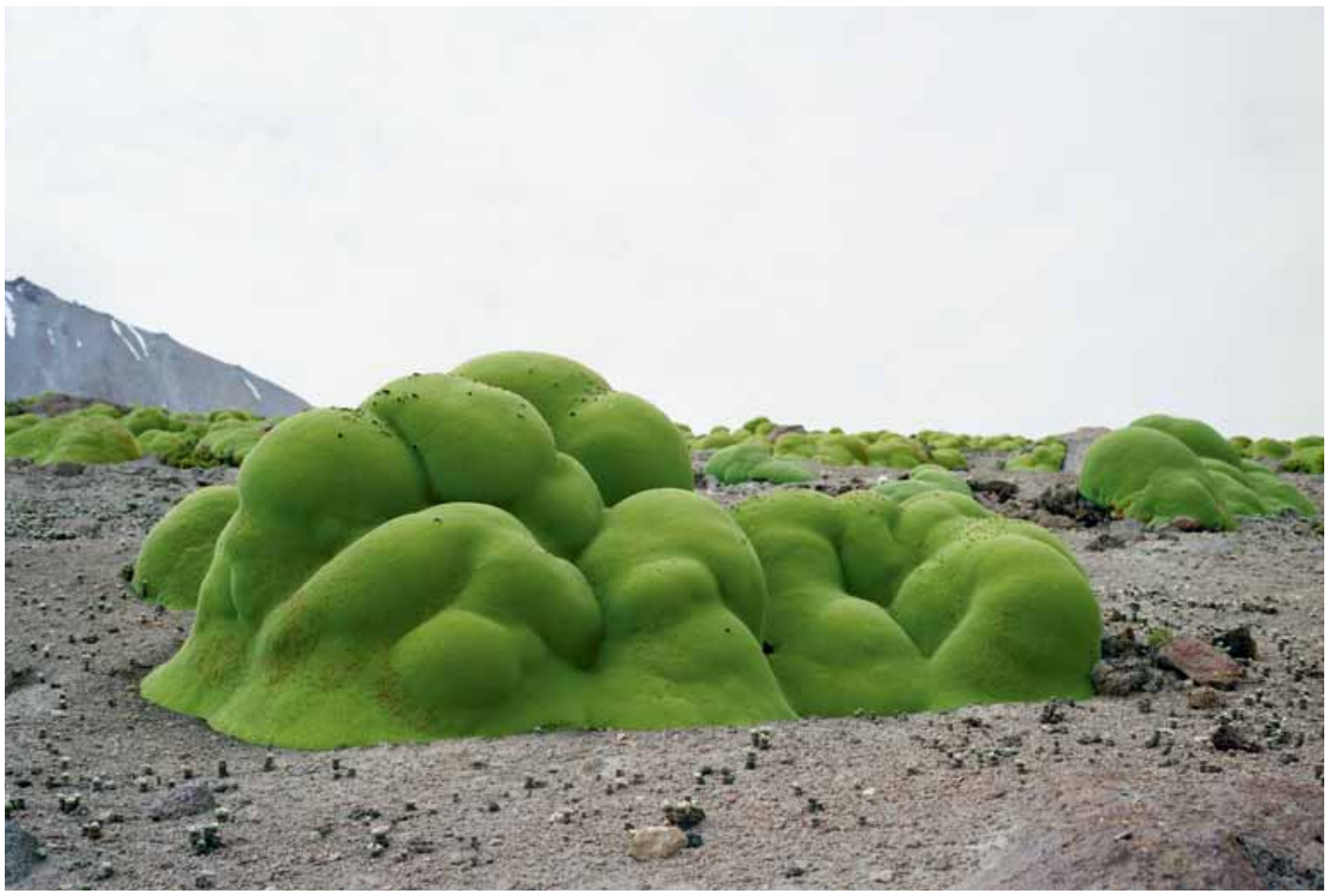

- REALLABORE UND TRANSDISZIPLINÄRE FORSCHUNG - SUSTAINABLE CONSUMPTION RESEARCH - SUSTAINABLE URBAN FOOD POLICY 


\title{
Governing Urban Food Systems in the Long Run
}

\author{
Comparing Best Practices in \\ Sustainable Food Procurement Regulations
}

Lukas P. Fesenfeld

\begin{abstract}
Today's food and agricultural systems are closely linked to pressing challenges for sustainable human life. Longer-term policy-making is seriously needed. Urban decision-makers have considerable power to shape the food and agricultural sector by, among other things, changing public food procurements towards greater sustainability.
\end{abstract}

Governing Urban Food Systems in the Long Run. Comparing Best Practices in Sustainable Food Procurement Regulations

GAIA 25/4 (2016): 260-270

\begin{abstract}
The aim of this comparative study is to explain variation in the ambitiousness of policy targets and the successful implementation of urban food policies in the cities of Zurich, Munich and Nuremberg. I conducted an in-depth process-tracing analysis of the mechanisms behind the adoption and implementation of 13 sustainable food procurement regulations officially adopted by the city councils from 2003 to 2014. In all 13 cases, high electoral safety, credible expectations of long-term policy benefits and high executive institutional capacity are necessary conditions for the adoption of longterm policies. However, they do not explain variation in target's ambition and implementation's success. Based on theory-building process-tracing, I argue that the variation in the degree of adoption and implementation success of long-term policies can be explained by five policy process and design features: 1 . deliberative and corporatist governance mechanisms, 2. a high level of central coordination for crosscutting policy implementation, 3 . involvement of decision-makers in policy networks, 4 . strong use of evidence-based instruments, 5 . bundling of short-term and long-term benefits.
\end{abstract}

\section{Keywords}

bundling, comparative study, corporatism, deliberation,

long-term governance, policy design, process-tracing,

sustainable food procurement, urban food policy, veto player

Contact: Lukas P. Fesenfeld, M. Sc. | Swiss Federal Institute of Technology Zurich (ETH) | International Relations, Bernauer | Haldeneggsteig 4 | 8092 Zurich | Switzerland |

E-Mail: lukas.fesenfeld@ir.gess.ethz.ch

(c) 2016 L. P. Fesenfeld; licensee oekom verlag. This is an article distributed under the terms of the Creative Commons Attribution License (http://creativecommons.org/licenses/by/3.0), which permits unrestricted use, distribution, and reproduction in any medium, provided the original work is properly cited.
$T$ oday's food and agricultural systems are closely linked to the most pressing challenges to sustainable human life such as climate change, the exploitation of natural resources, and antibiotic resistance. Notably, around 31 percent of global greenhouse gas (GHG) emissions are associated with the food system (Wellesley et al. 2015). ${ }^{1}$ Our food system is thus confronted with an increasing number of long-term problems, with cost implications reaching far into the future. Over 50 percent of the world population and over 70 percent of the European population (UN 2014) live in cities. Cities can act as a catalyst for societal and technological innovations to solve humans' most pressing challenges. One example of urban decision-makers' considerable power to shape the food and agricultural sector involves introducing urban food strategies and regulations with the goal to change public food procurements towards greater sustainability (Carey 2013, Lohrberg et al. 2015, Mansfield and Mendes 2013, Moragues et al. 2013, Morgan 2015, Moschitz and Kueffer 2016).

Sustainable food procurement regulations (SFPRs) are defined according to a number of concrete social, economic and environmental criteria (Barling et al. 2013, p.2) and aim to strengthen public procurement of seasonal, plant-based, local and organic food products. As policy instruments, they are sometimes integrated into more holistic urban food strategies ${ }^{2}$ to reduce the environmental footprint of food production and consumption and decrease future health costs related to poor nutrition. This study fo-

\footnotetext{
1 In terms of short-term climate effects and the risks associated with dangerous tipping points in the global climate system, agriculture contributes a disproportionate amount of high impact GHGs: approximately 47 percent and 58 percent of total anthropogenic emissions of $\mathrm{CH}_{4}$ and $\mathrm{N}_{2} \mathrm{O}$ respectively (Bajželj et al. 2014). It is estimated that the global economic benefits of dietary change could produce savings of about 1.5 trillion dollars by 2050 on healthcare, unpaid informal care and lost working days as well as reduced climate change damages.

2 Such strategies aim to integrate the complexity of urban food systems within a single policy framework, including food production, processing, distribution, access and waste management (Carey 2013, Mansfield and Mendes 2013, Moragues et al. 2013, Morgan 2015).
} 
cuses on SFPRs as an example of long-term policies, that is, policies that specifically tackle long-term problems such as climate change, water pollution or poor nutrition, which are all characterized by impacts beyond at least one human generation, deep uncertainty and substantial public good aspects (Hovi et al. 2009). The underlying objective of this comparative study is to explain the variation in target ambitiousness and successful implementation of 13 officially adopted food policies in the cities of Zurich (Switzerland), Munich and Nuremberg (Germany). Munich and Nuremberg serve as best practice examples for advanced sustainable food procurement and indicate high levels of policy success for some SFPRs, whereas Zurich indicates intermediate sustainable food procurement and serves as an enlightening comparative case.

\section{Foundations for Building a Theory of Long-term Governance}

I define long-term governance as all governing and decision-making processes taking place in long-term policies' adoption and implementation phases. These processes are not restricted to the state but also involve non-state actors. Jacobs $(2011,2016)$ derives three necessary conditions for long-term policy-making, namely, 1. electoral safety, 2. the generation of credible expectations of long-term social returns, and 3. institutional capacity. I hypothesize that all three conditions also need to be met with regard to long-term food policies such as SFPRs.

First, electoral safety rests on the assumption that voters evaluate policy-makers retrospectively but not prospectively (Nordhaus 1975). Thus, policy-makers face strong incentives to maximize shortsighted policy benefits because investing in long-term decisions can be a risky approach to securing votes (Jacobs and Matthews 2012). Jacobs $(2011,2016)$ hypothesizes that electoral safety for executive decision-makers is greater where electoral competitiveness is low (Kayser and Lindstädt 2015). He further argues that electoral risks are low if politicians have the opportunity to minimize the relative impact of short-term costs through policy design or strategic framing, and particular events focus voters' attention on long-term policy consequences.

Second, long-term policies will hardly be enforceable if longterm gains are perceived as out of reach. This problem results from individuals' discounting of future benefits. It is well established that people are not fully rational and exhibit short-term biases, placing more weight on short-term costs and benefits than on longterm benefits (Jacobs and Matthews 2015). Jacobs and Matthews (2012) lend support to the notion that this shortsighted policy bias is mainly caused by two kinds of long-term uncertainty: consequence uncertainty and political uncertainty. ${ }^{3}$ Jacobs (2011) claims that long-term policy investments are more likely if decision-makers' mental models (Gentner and Stevens 2014) - worldviews, ideas and mappings of the real world - include causal chains through which the investment can produce future net benefits instead of creating net costs.
Third, institutional capacity is a prerequisite for political institutions to "lend proponents within the state the capacity to enact policy investments" (Jacobs 2011, p. 29). Notably, it is the political system's openness to diverse societal groups that enables the adoption of long-term policies with high investment costs for organized interests. Nevertheless, knowing the conditions that enable long-term policies in the first place does not explain long-term policies' varying success rates.

\section{Methodology}

\section{Process-tracing}

This small-N explorative and comparative study examines 13 SFPRs officially adopted by three European city councils between 2003 and 2014. The empirical research was conducted between November 2014 and March 2015. I employ a two-fold strategy using a mixture of theory-testing and theory-building process-tracing ${ }^{4}$. First, I test Jacobs' theoretical conditions for long-term policy-making. Second, I inductively analyze the fundamental mechanisms behind the adoption and implementation of urban food policies, in order to develop new theoretical arguments to explain variation in the success of long-term policies.

\section{Most Similar Cases Design}

I choose a most similar cases design, that is, comparing similar processes to understand the differences, for several reasons: first, I expect that Jacobs' $(2011,2016)$ three conditions for long-term policy-making all are present, thus making adoption of the $13 \mathrm{SF}$ PRs possible in the first place. Second, holding potentially influential contextual factors constant, this design enables clear focus on the effect of altering policy-process and policy-design factors in explaining varying outcome success (Beach and Pedersen 2013).

Zurich, Munich and Nuremberg were selected as a sample of the cities that have adopted and implemented SFPRs. Munich and Nuremberg were chosen due to high contextual similarity (same state/political system, geography, and socio-demographics). As described in table 1 (p. 262), Zurich offers slight but interesting variation with respect to its progress towards a sustainable urban food system. Munich and Nuremberg serve as best practice cases for the adoption and implementation of SFPRs, whereas Zurich has been employed as a less successful, comparative case. Comparing best practice cases with some degree of variation in both the outcome as well as the explanatory factors suits the most similar cases design, chosen to specify the causal mechanism under-

\footnotetext{
3 Consequence uncertainty relates to risks in complex, long-term processes, that is, discounting future benefits might be rational as there is no complete certainty that they can be realized (Bernauer 2013, Jacobs 2016). Political uncertainties relate to well-known problems of time inconsistency (Kydland and Prescott 1977), that is, politicians face the incentives to revise prior political decisions to serve short-term goals.

4 Process-tracing can be defined as the analysis of a chain of events causing observed outcomes (George and Bennett 2005).
} 
TABLE 1: Urban food governance in Munich, Nuremberg, and Zurich: comparison of relevant contextual factors.

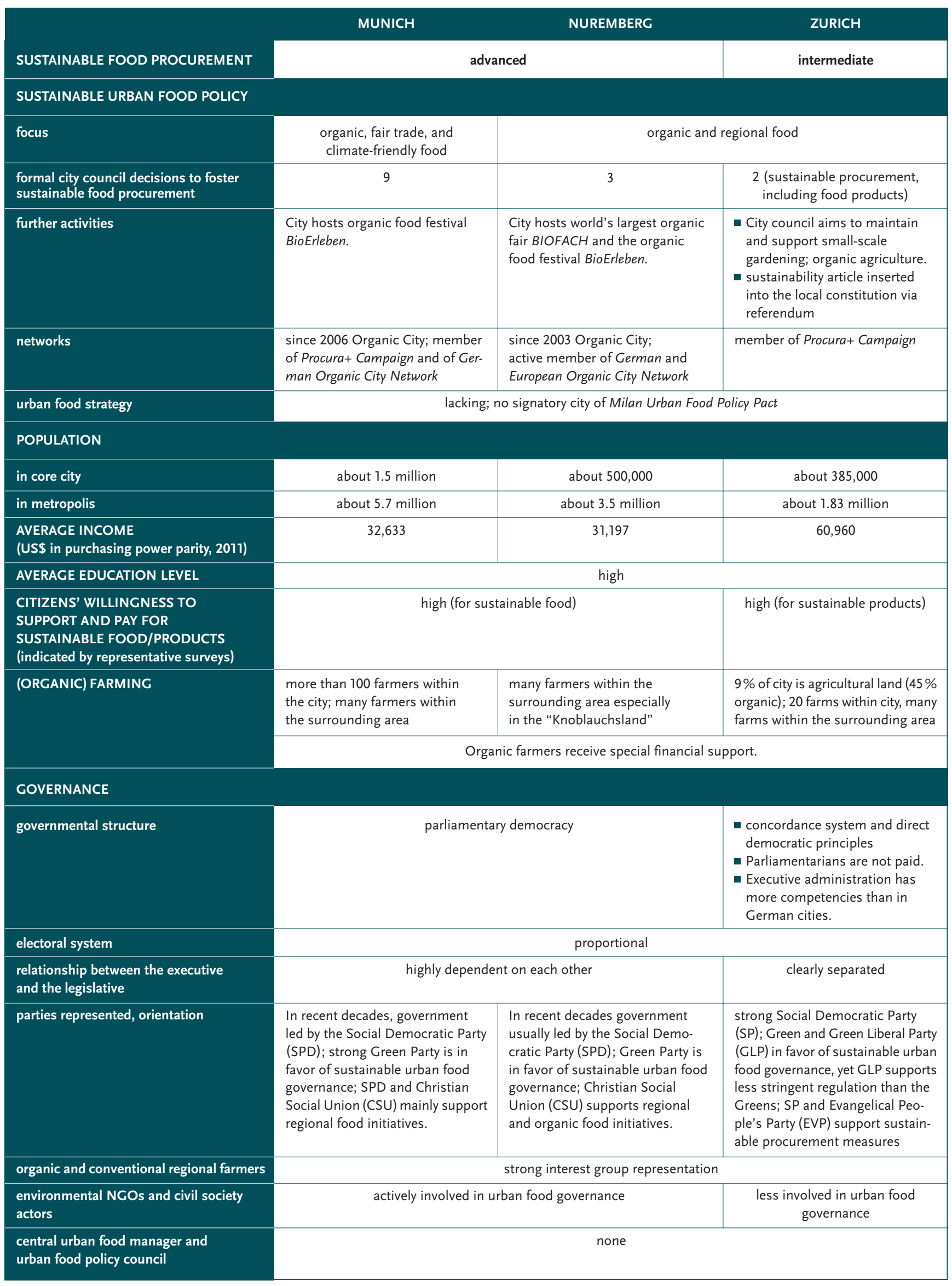


BOX 1:

\section{Sustainable Food Procurement Regulations (SFPRs) Adopted by the City Council of Munich, 2006 to 2013}

SFPR M1 (20/07/2006): increase certified organic and regional food products in schools and kindergartens; certify Munich as an organic city; increase the percentage of certified organic food in city's public canteens (percentage not specified); spread information on organic products in private restaurants (Vorlagen-Nr. 02-08/V 08321)

SFPR M2 (27/06/2007): 50 percent certified organic and regional food products in public day nurseries and kindergartens by 2010 (Vorlagen-Nr. 02-08/V 09971)

SFPR M3 (08/10/2008): continue the Bio for Kids project to increase the percentage of certified organic products in schools; establish new project manager to coordinate projects to increase consumption of organic products in private restaurants and public canteens (percentage increase not specified) (Vorlagen-Nr. 08-14/V 00965)

SFPR M4 (11/12/2008): decrease percentage of animal products in public canteens (percentage not specified) (Vorlagen-Nr. 02-08/V 01344)

SFPR M5 (23/11/2011): investments into new cook and chill (energy-saving) kitchen infrastructures in schools (five million euros per year); 50 percent certified organic products; 30 percent fresh products and increase percentage of regional products in schools (Vorlagen-Nr. 08-14/V 06751)

SFPR M6 (14/12/2011): increase number of certified fair-trade and organic products procured for all public city departments (VorlagenNr. 08-14/V 06533)

SFPR M7 (27/02/2013): 50 percent certified organic food products in full-time day schools and day nurseries; the other 50 percent sustainable and healthy products, e.g., MSC-fish, meat from animals kept in a near-natural environment; cook and chill system as general standard cooking system in public canteens; embed topic Food and Food Culture into the educational work of schools and day nurseries; increased procurement of regional and seasonal products (VorlagenNr. 08-14/V 10745)

SFPR M8 (02/05/2013): 20 percent certified organic and regional products in procurement for all public city departments (VorlagenNr. 08-14/V 08524)

SFPR M9 (25/09/2013): expert report on how to increase procurement of certified organic and regional products in all public city departments to more than 20 percent (Vorlagen-Nr. 08-14/V 12487)

lying policies' long-term success (Przeworski and Teune 1970). Moreover, cases were selected according to a set of factors empirically shown to correlate with higher willingness to adopt pro-environmental legislation and willingness to pay for sustainable (food) products (Franzen and Vogl 2013, Hunter et al. 2004). The German cities are comparable in terms of their median voters' average education level, income level, age structure and gender ratio. Again, Zurich offers some interesting distinctions in terms of the political system (direct democratic and concordance based) and income level. Below, based on the process-tracing analysis, I discuss the degree to which variation in the political system may explain variation in policy success between the two German cities and Zurich.
BOX 2:

\section{Sustainable Food Procurement Regulations (SFPRs) Adopted by the City Council of Nuremberg, 2003 to 2014}

SFPR N1 (23/07/2003): ten percent certified organic and regional food products in all public canteens by 2008 (City Council Decision 23/07/2003)

SFPR N2 (15/10/2008): 50 percent certified organic products in schools and day nurseries, in weekly markets and during catering for all mayor's office events; 25 percent certified organic products for all public canteens and during catering for other city events; ten percent of total farmers in and around Nuremberg are certified organic farmers (City Council Decision 15/10/2008)

SFPR N3 (22/10/2014): 75 percent certified organic products in schools and day nurseries; 50 percent certified organic products in weekly markets and during catering for all official city events; 25 percent certified organic products in all public canteens; 20 percent of total farmers in and around Nuremberg are certified organic farmers (City Council Decision 22/10/2014)

BOX 3: Sustainable Food Procurement
Regulations (SFPRs) Adopted by the
City Council of Zurich, 2010 to 2014

SFPR Z1 (17/03/2010): increase procurement of fair trade products and products in line with international labor standards in all public city departments and canteens (StZH_StRB_2010_0459)

SFPR Z2 (19/11/2014): increase procurement of certified organic, seasonal and less energy-intensive products in all public city departments and canteens (StZH_StRB Nr. 976/19.11.2014)

\section{Data Collection}

The cities were chosen from the Sustainable Procurement Resource Centre dataset. ${ }^{5}$ The data analysis was complemented with cases from the European Commission-funded FoodLinks research project (Barling et al. 2013). SFPRs define binding or nonbinding goals for the public procurement of sustainable food products. Most SFPRs specify concrete percentages of sustainable food to be procured within a defined timeframe, yet some SFPRs lack this specificity. Box 1 (Munich), 2 (Nuremberg) and 3 (Zurich) summarize detailed information about all SFPRs officially adopted by the respective city councils between 2003 and 2014 .

The study follows a twofold data selection strategy. First, all available primary documents -27 newspaper articles, 13 regulation documents, 21 protocols and 20 reports/expert studies ${ }^{6}$ - were systematically analyzed to identify factors explaining adoption and implementation success. The documents cover both the adoption and implementation phases of all 13 official SFPRs. The documents were selected based on extensive online and desk research

5 www.sustainable-procurement.org

6 A list of all documents that were analyzed can be received upon request. 
TABLE 2: Measurement scale for adoption success (i. e., level of policy target ambition).

\begin{tabular}{|c|c|}
\hline LEVEL & MEASURE \\
\hline I & no adoption of regulation \\
\hline II & $\begin{array}{l}\text { adoption of a legally binding regulation stating a political goal for sustainable public procurement not specifying an exact percentage of } \\
\text { sustainable food in public canteens nor any exact SFPR criteria }\end{array}$ \\
\hline III & $\begin{array}{l}\text { adoption of a legally binding regulation specifying an exact percentage of sustainable food products in public procurement that does not go } \\
\text { beyond the status quo of sustainably procured food products at the time of adoption }\end{array}$ \\
\hline IV & $\begin{array}{l}\text { adoption of a legally binding regulation specifying an exact percentage of sustainable food products in public procurements that does go } \\
\text { beyond the status quo of sustainably procured food products at the time of adoption }\end{array}$ \\
\hline
\end{tabular}

as well as via snowball sampling of experts and interviewees. Second, I conducted 24 semi-structured elite interviews ${ }^{7}$ with decision-makers from different political parties, administrative units, civil society groups, journalists, researchers and consultants both in person and via phone, in order to deepen my understanding of the adoption and implementation processes. I selected these interviewees based on the results of the primary document content analysis and online desk research.

\section{Adoption and Implementation Success}

The estimated level of adoption and implementation success for the 13 SFPRs is a qualitative measure. It is based on triangulated quantitative and qualitative data from the document content analysis and the interviews. To measure adoption success, that is, the policy's level of ambition towards sustainable food procurement, the SFPRs were grouped into four categories, where category I indicates the lowest level of policy ambition and category IV the highest (table 2). Box 4 provides an example assessment of adoption success.

To measure implementation success I grouped the 13 SFPRs into five categories (table 3). Implementation success is a combined measure of quantitative and qualitative data available for each respective SFPR. Quantitative data entail statistics available on the level of food procurements. In eleven cases these statistics are based on non-verifiable surveys administered by the administration to public caterers, canteens and decentralized procurement officers, while in two cases the statistics are based on exact centralized accounts of public procurements. I combined available quantitative data with the interviewees' assessments. I triangulat-

\section{BOX 4: Example Assessment of Adoption Success: SFPR N2}

Specific and Ambitious Goal:

The council decision states the specific goal that 50 percent certified organic products have to be offered in schools and day nurseries. This goal specifies an exact percentage of sustainable food products in public procurements that goes beyond the status quo of sustainably procured food products at the time of adoption. The previous SFPR $\mathrm{N} 1$ from 2003 stated the goal of ten percent certified organic products.

\section{Evaluation:}

High degree of adoption success, i.e., the policy ambition is specific and goes beyond previous targets. ed all available data to group SFPRs according to the level of implementation success. This measure is restricted by data availability as well as the subjective evaluations of interviewees. An example evaluation of implementation success is provided for in box 5 .

\section{Towards a Theory of Long-term Governance}

Necessary Prerequisites for Adopting and Implementing SFRPs I was able to confirm that Jacobs' $(2011,2016)$ three conditions must be present in order to make the adoption of the 13 SFPRs possible. I found convincing evidence that Jacobs' first condition for long-term policy-making - electoral safety - was fulfilled. To quote one interviewee, for example, "The scandals opened a window of opportunity in which we faced little electoral risks to push for the adoption of higher organic requirements in public food procurements" (IM 11). Overall, electoral safety for executive decision-makers was high in all three cities since the topic of sustainable food enjoyed broad public support.

The second crucial condition for long-term policies is that decision-makers' mental models include causal dynamics where policy investment produces net social benefits in the future. Empirical findings from all three cities confirm that key decision-makers perceived the SFPRs' social benefits as credible. For instance, an interviewee in Zurich stated, "We believe that high environmental and social procurement standards will eventually reduce costs for the citizens of Zurich" (IZ 8).

Finally, the empirical findings support Jacobs' third argument that institutional capacity is a necessary condition for long-term policies. Most SFPRs in the three cities entailed relatively small costs to organized interests. Therefore, the executive faced little opposition and its institutional capacity was high. In cases with high investment costs for organized interests, the executives' institutional capacity was greater if the degree of institutional insulation was very low, meaning diverse interest groups had the possibility to voice their concerns and none was able to monopolize influence on political decision-makers. This was the case during the

7 See Aberbach and Rockman (2002) for method. A list of the anonymous interviews can be received upon request; interviews are cited as follows: interview (I) Munich (M)/Nuremberg (N)/Zurich (Z) number. 
TABLE 3: Measurement scale for implementation success.

\begin{tabular}{ll} 
LEVEL & MEASURE \\
I & goals not implemented \\
\hline II & low degree of implementation \\
\hline III & intermediate degree of implementation \\
\hline IV & high degree of implementation \\
\hline V & goals fully implemented \\
\hline
\end{tabular}

adoption and implementation of M5 and M7 in Munich: "We all sat at one table. Everyone could voice their concerns and preferences" (IM 14).

\section{Explaining the Variation in the Adoption and Implementation Success of SFPRs}

Table 4 (p. 266) presents five factors that I induced to explain the variation in the level of adoption and implementation success of the 13 analyzed SFPRs. In terms of both the level of ambition and the respective implementation success, the most successful SFPRs are SFPR M2, M5 and M7 in Munich. None of the 13 SFPRs has been fully implemented (level V). In the discussion I show that both the adoption and implementation success of long-term policies such as SFPRs is highest if all five policy design and process factors are present and (very) influential, that is, significantly shape the decision-making processes. Overall, the five factors prove to be more influential in Munich and Nuremberg than in Zurich. This elucidates why SFPRs are more successful in the two German cities.

The current theories do not explain which factors lead to variation in the 13 SFPRs' adoption and implementation success. To answer this question, I conducted theory-building process-tracing. The following five arguments relate first to three policy process factors and second to two policy design factors. I will discuss these arguments in the context of urban food policy, specifically SFPRs, in order to contribute to the ongoing debate on long-term governance.

\section{Policy Process Factors}

ARGUMENT 1: The existence of deliberative and corporatist governance mechanisms such as multi-sectorial food governance fora positively affects the adoption and implementation of long-term policies (e.g., SFPRs).

Democratic corporatist governance is characterized by a set of stable veto-rights for relevant stakeholder groups, enabling problem-solving through cooperation, consultation, negotiation, and compromise (Lijphart 2012, Schmitter and Lehmbruch 1982). Multi-sectorial governance fora, such as urban food policy councils, are to be distinguished from pure consultation fora. Their purpose is not only to inform stakeholders and gather information to support policy drafting and implementation processes, but also to officially (i.e., transparently) and regularly invite stakeholders to join the process of drafting and implementing policies. However,

\section{Example Assessment of Implementation Success: SFPR M7}

Quantitative Evaluation: High Degree of Implementation In the 2013 public tender, two out of three procurement lots (value of 13 million Euros) were implemented. In these tenders the 50 percent criteria are fixed as legally binding standards. The control system is ensured via a central audit.

\section{Qualitative Evaluation: High Degree of Implementation}

- Triangulated interview data has revealed that the cook and chill system has been installed in approximately 75 percent of all full-time schools and day nurseries after the adoption of the regulation.

- The school department consults day nurseries and schools how to use the new cook-system and how to integrate the topic Food into the educational work. Since the adoption of the SFPR, the school and environmental department organized in cooperation with an environmental nongovernmental organization (NGO) about 40 inhouse consultancies and events (e.g., cooking trainings, farmer markets, farmer visits) for educational institutions and their staff.

elected and official representatives in the legislative and executive branch always make the final decisions about policy adoption and concrete implementation. My empirical analysis shows that deliberative and corporatist bargaining institutions offer veto rights to all stakeholders, making policy change more costly and policy enforcement more credible. This, in turn, has a positive effect on implementation success. In the SFPR adoption and implementation processes in which NGOs actively engaged in multi-sectorial fora (i.e., M1, M2, M5, M6, M7, N2, N3), executive accountability and thus, the costs of reversal increased (IM 9, 10, IN 18, 23).

Further, I conclude that granting diverse interest groups broader access to the adoption and implementation process reduces the risk of redistributive policy solutions, which disadvantage certain groups over time. The multi-sectorial fora increased the likelihood that those who will eventually benefit from the long-term policy cover the short-term costs (M1, M2, M5, M6, M7, N2, N3). This is in line with arguments by Lijphart (2012) and Tsebelis (2002) regarding the stability of policy outcomes as the number of veto players increases. Nevertheless, there may be a tension between the level of target ambition and implementation success. I have previously argued (Fesenfeld 2012) that corporatist institutional design typically leads to incremental, nonradical policy change and thus to higher policy implementation success. In corporatist settings, policy adoption rests on a compromise between the most powerful stakeholders who, consequently, do not hamper the implementation process once they agreed to a policy's adoption. However, establishing sustainable food systems may require radical and disruptive decisions. Incrementalism, for example, may not sufficiently reduce the consumption of animal products and consequentially, GHG emissions. According to Tsebelis (2002), such far-reaching reforms should be less feasible if the number of involved veto players increases. Thus, one may question if corporatist and deliberative institutional settings can ever enable fundamental policy change? 
TABLE 4: Overview of adoption and implementation success. ${ }^{a}$ Table 4 summarizes the empirical findings and presents five policy design and process factors explaining the variation in the level of adoption and implementation success. The most successful SFPRs are SFPR M2, M5 and M7 in Munich. $-/ /+/ /++=$ factor is not present/influential // influential // very influential; see tables 2 and 3 for measure of policy success.

\begin{tabular}{|c|c|c|c|c|c|c|c|}
\hline \multirow{3}{*}{$\begin{array}{l}\text { LONG-TERM } \\
\text { POLICY } \\
\text { no. SFPR } \\
\end{array}$} & \multicolumn{5}{|c|}{$\begin{array}{l}\text { LONG-TERM GOVERNANCE FACTORS EPLAINING VARIATION IN ADOPTION AND } \\
\text { IMPLEMENTATION SUCCESS OF LONG-TERM POLICIES (THEORY BUILDING) }\end{array}$} & \multirow{3}{*}{$\begin{array}{l}\text { ADOPTION } \\
\text { SUCCESS } \\
\text { success level }\end{array}$} & \multirow{3}{*}{$\begin{array}{l}\text { IMPLEMENTATION } \\
\text { SUCCESS } \\
\text { success level }\end{array}$} \\
\hline & \multicolumn{3}{|c|}{ POLICY PROCESS FACTORS } & \multicolumn{2}{|c|}{ POLICY DESIGN FACTORS } & & \\
\hline & multi-sectorial fora & high-level coordination & policy networks & evidence-based & bundling benefits & & \\
\hline \multicolumn{8}{|l|}{ MUNICH } \\
\hline M1 & + & - & + & - & + & II & IV \\
\hline M2 & + & ++ & + & ++ & ++ & IV & IV \\
\hline M3 & - & + & ++ & - & + & II & IV \\
\hline M4 & - & - & + & + & - & II & II \\
\hline M5 & ++ & ++ & ++ & ++ & + & IV & IV \\
\hline M6 & ++ & + & ++ & - & - & II & III \\
\hline M7 & ++ & ++ & ++ & ++ & + & IV & IV \\
\hline M8 & - & + & ++ & ++ & ++ & III & III \\
\hline M9 & - & + & + & ++ & - & II & II \\
\hline \multicolumn{8}{|l|}{ NUREMBERG } \\
\hline N1 & - & + & + & + & ++ & III & IV \\
\hline N2 & ++ & + & ++ & + & + & IV & III \\
\hline N3 & ++ & + & ++ & + & + & IV & not available \\
\hline \multicolumn{8}{|l|}{ ZURICH } \\
\hline Z1 & - & + & + & + & + & II & II \\
\hline \multirow[t]{2}{*}{$\mathbf{Z 2}$} & - & + & + & + & + & II & II \\
\hline & \multicolumn{5}{|c|}{ VARYING EXPLANATORY FACTORS } & \multicolumn{2}{|c|}{ VARYING OUTCOMES } \\
\hline
\end{tabular}

a Due to space limitations, not all process-tracing findings regarding the specific adoption and implementation processes of each single SFPR can be fully discussed in this article. They are available from the author upon request.

In fact they can: the corporatist nature of multi-sectorial fora composed of larger numbers of stakeholders holding diverse political and economic interests reduced politicians' electoral risks for politicians by diffusing blame for the short-term costs of the SFPRs. Stakeholders could also more easily diffuse blame on others. In this way, organized interest groups - such as farmer associations - were able to justify costly investments to their constituencies. My analysis thus indicates that contrary to Tsebelis' veto player theorem (2002), more ambitious SFPRs could be adopted if they were supported by diverse stakeholders (see M2, M5, M7, N2, N3) compared to those that were not (see M3, M4, M8, M9, N1, Z1, Z2). This implies that blame avoidance is a particularly relevant factor for both politicians and organized interest groups and can explain variation in long-term policy ambition.

Moreover, the deliberative setting of multi-sectorial food fora enables stakeholders to 1 . better voice their doubts about the credibility of a policy's long-term net benefits and 2. actively influence the adoption of more credible goals so that 3 . long-term policies' words-deeds gap ${ }^{8}$ is effectively reduced. In Munich and Nuremberg, regular official roundtables and working group meetings created trust between diverse stakeholders (including catering firms, farmers, NGOs) and administrative staff in charge of policy formulation and implementation (IM 9, 10, 12, 13, IN 18, 22). Higher levels of trust created an open atmosphere, in which stakeholders could voice their concerns and preferences, actively engage to find compromises and exchange knowledge and information. An interviewee stated, "The working atmosphere was very constructive and open. We knew that all information and opinions exchanged during the meetings would 'stay in the room.' In such an atmosphere we could engage in fact-based discussion" (IM 12). Including stakeholders' expertise regarding implementation hindrances effectively reduced policies' words-deeds gap (IM 10,14) and led to the most ambitious and successful SFPRs (see M2, M5, M7, N2, N3).

The lack of regular round tables and multi-sectorial working groups in Zurich partly explains why their procurement standards are less concrete and far-reaching. Interviewees in Zurich placed the responsibility for low implementation success on the vagueness of the directives and resulting public tenders (IZ 3, 7). One interviewee stated, "No official staff has approached us to ask for our opinion or to invite us to participate in any working group if we had the chance to do so, we would have told them that the directives are too vaguely phrased" (IZ 3). Furthermore, how these three cities' political systems differ partly explains variation in policy success. In Zurich, parliamentarians are not paid, and the executive enjoys greater liberty to independently specify and implement regulations. The time resources of honorary parliamentarians are highly constrained. For this reason they primarily focus

\footnotetext{
8 The words-deeds gap in long-term policy-making relates to the problem of time-inconsistency (Kydland and Prescott 1977), that is, politicians have an incentive to propose a far-reaching policy at point (a) in time and change their position at point (b) in time.
} 
on drafting broad regulations instead of specifying concrete goals or acting as a "watchdog" to ensure the successful implementation of already adopted regulations. ${ }^{9}$ An interviewee stated, "If we want to win new votes, we need to advance new policy issues instead of focusing on controlling the successful implementation of old regulations. We also may only set broad goals and leave the specifics to the administration. We lack both time and knowledge to enact far-reaching, concrete regulations" (IZ 1).

My empirical findings are in line with studies from other research fields. It is argued that deliberative and corporatist governance mechanisms diffuse policy accountability and increase involved stakeholders' knowledge and the costs of policy reversal, which may explain the adoption and implementation of less popular policies (Boston 2016, Jacobs 2016, MacKenzie 2016, Scruggs 2001, Weaver 1986).

\section{ARGUMENT 2: In the case of crosscutting long-term policy issues, central coordination at a higher hierarchical level (e.g., the mayor's office) increases administrative capacities and positively affects long-term policies' implementation.}

Administrative capacities are defined as "the set of skills and competencies that are expected of public bureaucracies so that they can facilitate and contribute to problem-solving" (Wegrich and Lodge 2014). Administrative capacities are to be distinguished from Jacobs' (2011) definition of institutional capacity. Administrative capacities encompass the administrations' coordination, analytical, regulatory and delivery capacities (Wegrich and Lodge 2014) yet do not relate to the openness of the decision-making process (Jacobs 2011). It is argued that the level of administrative capacities determines how effectively governments are able to solve problems (Wegrich and Lodge 2014). Like many other long-term challenges, food is a crosscutting policy issue incorporating aspects from health, environmental, infrastructural and educational domains. Coordination capacities decrease in cases where no central coordinator is able to issue authoritative instructions, resolve turf battles (McGuire and Agranoff 2011), create synergies and effectively organize decentralized implementation activities. Traditionally, food policy and procurements have not been centrally organized in any of the three cities (IZ 4, IM 14, IN 18). The dependency on decisions by individual administrative staff members and procurement coordinators in different departments hindered most SFPRs' effective implementation. Decisions were contingent on subjective preferences and knowledge (IZ 4, IM 9, 14, IN 18). In all three cities, the environmental and health departments pushed the issue of sustainable food procurement forward (IZ 4, 6, IM 9, 10, 11, 12, IN 18, 20, 21, 23, 24). Nevertheless, these departments had no authority to issue instructions to other departments in charge of food procurements (e.g., the schooling department) and urban planning decisions (e.g., construction department) (IZ 4, 6, IM 9, 13, IN 18, 24). An interviewee in Munich stated, "We cannot effectively organize the implementation of the Biostadt project and the other SFPRs because we do not have the official authority to give instructions to other departments that are in charge of specific implementation steps" (IM 9). In the rare cases (M7, Z1) that instructions were issued by higher-level staff, the implementation process was significantly sped up and turf battles between departments could be resolved (IZ 6, IM 13).

In all three cities, the analytical capacity to assess the SFPRs' implementation process and plan was severely undermined by the lack of a central data collection system. In fact, besides M5 and M7, none of the three cities was able to exactly measure the total number of food products different departments and public entities procured (IZ 4, 6, IM 9, 14, IN 18, 24). The assessment of procurement in all public canteens and events is still diffusely organized by different departments and relies on self-reporting surveys instead of a central digital procurement system (IM 14).

Finally, in order to reduce the risks of procurement managers being captured by catering firms' private interests, the procurement staff in Munich responsible for practical implementation of the public tenders resulting from M5 and M7 was effectively monitored by two higher-level administrative departments (IM 12). Compared with all other SFPRs, the delivery capacity has been highest in these two cases.

All in all, interviewees suggested that the implementation of crosscutting issues such as food policy should be centrally coordinated at a higher hierarchical level in order to increase administrative capacities (IZ 6, IM 9, 12, IN 18, 24): “Sometimes I wish that we in the Biostadt project would be incorporated into the mayor's office. Then we would finally have the necessary authoritative capacities to centrally organize and effectively implement the food regulations" (IM 9).

\section{ARGUMENT 3: Executives' participation in policy networks positively affects long-term policies' adoption and implementation.}

The variation of policy success can be explained by policy networks (Rhodes 2006). Policy network analysis stresses the importance of epistemic communities and groups of actors sharing similar beliefs and interests (Haas 1992). Policy networks foster processes of socialization and knowledge exchange, thereby influencing policies' adoption and implementation (Sabatier 1987). All three cities have officially participated in superregional policy networks. Variation in levels of implementation success can be explained by differing degrees of executive staff involvement in network activities. Most important are the Procura+ Campaign initiated by Local Governments for Sustainability (ICLEI) which supported public authorities' implementation of sustainable public procurements, the European Organic City Network (Biostädtenetzwerk) initiated by Italian urban policy-makers and the German Organic City Network. These networks organized regular meetings between policy-makers, experts and administrative staff of participating administrations across Germany, Europe and the world.

9 Since the regulations' adoption, the parliament has not made use of its legal means (e.g., interpellations and postulates) to receive detailed information about the status quo of the SFPRs' implementation [IZ 1, 5]). 
Involvement in policy networks should increase delivery capacity due to comparison and competition between the network members, that is, increasing pressure on the executive to achieve higher policy success. The interviews revealed that competition between cities played a role in setting far-reaching sustainability goals for public food procurements, particularly in Munich (M5, M6, M7, M8) and Nuremberg (N2, N3) (IM 11, 12, IN 18, 24). Comparison to other cities helped urban decision-makers to legitimize ambitious policy targets. An interviewee stated, "Yes, we do compare each other. Other cities in Europe such as Vienna and Malmo are steps ahead of us" (IN 24).
RIA). Evidence-based instruments can take on such forms as urban food maps which offer a product-flow analysis of regional food production and consumption streams to optimize logistical and environmental performance and inform targeted policy interventions (Carey 2013, Moschitz et al. 2015). These assessments can be crucial for fact-based and efficient decision-making.

Expert reports played a significant role in the decision-making processes of several SFPRs, especially in Munich (M2, M5, M7, M8, M9). Policy-makers and administrative staff used such reports to better understand the complexity of food markets' regulation (IM 9, 10, 12, 13, 17, IN 18). In Munich, the expert reports

\section{The variation in the degree of adoption and implementation success of long-term policies such as SFPRs can be explained by five policy process and design features.}

Furthermore, a city's administrative staff's participation in the policy networks and epistemic communities fostered information and knowledge sharing, and, among other things, increased cities analytical capacities. For instance, an interviewee in Zurich indicated a regular exchange of expertise with other cities participating in the ICLEI campaign (IZ 6). This research showed that knowledge exchange and the resultant policy learning is especially important with regard to complex policy problems such as sustainable food policy. In all three cities, interviewees argued that participation and knowledge exchange in policy networks had been useful to draft SFPRs and saved resources in the policy implementation phase (IZ 6, IM 13, IN 18).

Finally, interviewees who actively participated in policy networks perceived SFPRs' long-term benefits to be more credible, and as a result of their participation, they were more motivated to pursue policy implementation (IZ 6, IM 13, IN 18). In this sense, individual staff members' participation in policy networks and epistemic communities had socialization effects shaping decisionmakers' mental models and increasing their intrinsic motivation to successfully implement SFPRs. An interviewee argued that network events helped them to "stay motivated because we saw what is possible in other cities and received positive feedback about our own work" (IZ 6). In fact, these empirical findings coincide with research in the field of climate change politics. Schaffer (2011) argues that interdependent decision-making between cities is not dependent on geographical proximity but rather on comparable population sizes and cities' participation in municipal networks (see also Bulkeley 2010).

\section{Policy Design Factors}

ARGUMENT 4: The use of evidence-based instruments positively affects long-term policies' adoption and implementation.

Evidence-based instruments are studies prepared by independent experts and academics assessing the potential impacts of existing and prepared legal acts (regulatory impact assessments, were regularly employed as a legitimizing tool by SFPR proponents to justify long-term benefits. Reference to independent experts increased proponents' political standing (IM 10, 12, 13).

Furthermore, interviewees argued that the SFPRs' impact assessment by independent experts objectified the debate, reducing the role of prior normative beliefs and decreasing electoral risks (IM 9, 10, 12, 13, 17). Solid evidence for this claim includes the expert report the Munich parliament commissioned during M7's adoption process. This report, by Roehl and Fülles (2012), significantly reduced the salience of policy opponents' cost-argument and thus had a positive effect on adoption success (IM 9). Expert opinions and reports were particularly important in SFPRs involving higher investment costs (M5, M7).

Moreover, expert reports were especially useful in objectifying the decision-making process when SFPRs' adoption faced strong opposition (IM 9, 10, 12). In Munich, M9 opponents argued that increased food prices would target the poor (IM 9, 10, 15, 17). Contrarily, an officially commissioned expert report indicated that several standards (e.g., ten percent organic products, 30 percent regional products, 100 percent fair trade coffee) could be implemented in the city's canteens without any significant price increases (Stadt München 2013). This was crucial to reduce opposition: "The expert report showed that prices for more sustainable meals do not (...) necessarily increase as much as we thought they would. Thanks to the report, today we fully support the policy's implementation" (IM 17).

Experts were invited to share information with decision-makers during the implementation processes in Nuremberg and Munich. For instance, Nuremberg's environmental department arranged an ongoing partnership with a local university to exchange knowledge about regional and sustainable food systems on a regular basis (IN 18, 24). In Munich, independent experts consulted the administration during the formulation process of large-scale public tenders (IM 13, 14). According to interviewees, specialists facilitated the implementation process: "Experts have a more objective point of view than policy-makers" (IM 14). 
ARGUMENT 5: The promise of short-term and long-term benefits in the policy design positively affects long-term policies' adoption and implementation.

Decision-makers and citizens have a short-term bias with regard to costs and gains. When policy benefits are visible in the short-term and not only in the long run, decision-makers and their constituencies perceive short-term costs and investments as less painful. This is in line with psychological literature on loss aversion (Kahneman and Tversky 1984, Milkman et al. 2012). For example, the short-term success of the Bio für Kinder project in Munich (i.e., 32 day nurseries changed their daily menus to organic and healthy dishes without significant cost increases) was an important argument during SFPR M2's adoption phase. The project's visible short-term success made the policy's long-term benefits credible. Similarly, the Biobrotbox campaign in Nuremberg schools increased the perceived credibility of N2 and N3's long-term benefits. An interviewee argued, "Parents see that our policies work today and therefore also believe that they will be beneficial in future" (IN 24). This is in line with the concept of anchoring (Sunstein 2014). People tend to choose a familiar reference point to judge unknown parameters; in this case, the Bio für Kinder project's short-term success was used to evaluate the credibility of related SFPRs' long-term success.

In all three cities, positive reputational and marketing effects played an important role in political decision-makers' support of SFPRs, and the issue of sustainable food enjoyed broad public support. Interviewees (IM 11, 12) underscored that SFPRs adoption was actively used to gain votes (e.g., M8). In Nuremberg (N2, N3) and Munich (M7, M8, M9), the festival Bio Erleben presented organic farming initiatives and drew citizens' attention to "the fun of food" (IN 18). During these events, regional farmers and the government in particular gained a positive public image, and enjoyed marketing and reputational benefits. In this sense, adopting long-term policies had a direct short-term payoff to individual political decision-makers and stakeholders. to the world wide largest organic fair BIOFACH in Nuremberg (IN 18, 21, 23).

\section{Conclusion}

Based on my findings, I recommend

1. developing official multi-sectorial governance fora such as urban food councils. These fora are necessary to embed SFPRs within comprehensive urban food strategies, share knowledge, and increase support from various stakeholders in the food system.

2. Additionally, central food policy coordinators at a higher hierarchical level (e.g., the mayor's office) should coordinate the approach to this crosscutting and complex issue.

3. Moreover, executive staff should regularly participate in policy network and training events to foster learning, knowledge transfer and information exchange.

4. Furthermore, decision-makers should make more use of evidence-based policy instruments. Two promising approaches for evidence-based instruments are urban food maps and rigid policy impact assessments. To objectively structure and inform the policy design and implementation process, policy-makers should seek advice from independent experts and consultants.

5. Finally, it is extremely important to design policies and policy mixes that generate short-term co-benefits for decision-makers, stakeholders and citizens. Urban food policy designs could incorporate funds that reduce risks to catering firms during the introduction phase of SFPRs, offer redistributive measures to low-income groups or employ information campaigns to increase awareness of the policies' positive health and economic externalities. Thinking ahead, in light of the current refugee crisis, valuable synergies between urban food and integration policies can be created. Moreover, carefully designed nudges and incentive structures in canteens can bundle short-term

\section{Innovative sustainable urban food policies can only achieve success if decision-makers comprehend and acknowledge the crosscutting and long-term nature of food systems.}

Policies were also consciously designed and framed in a way to yield short-term personal payoffs to key decision-makers. For instance, in Munich, a private non-profit fund was established to reduce the financial risks for caterers changing canteen menus. The public-private policy design decreased the need for public investments and in turn, eased the pressure on political leaders to justify the adoption of M2. Lower electoral risks and high reputational gains for executive decision-makers increased short-term incentives to support SFPR adoption. Analysis of N1 in Nuremberg yielded similar findings. Key decision-makers had both political (e.g., lower electoral risks) and economic short-term cobenefits (e.g., positive marketing effects) from linking the policy and long-term benefits. Overall, increasing the salience of shortterm and long-term gains over losses is an essential prerequisite for successful adoption and implementation of long-term policies such as SFPRs.

Further research is necessary to evaluate the full complexity of urban food governance. Particularly, transdisciplinary and comparative research on urban food policy councils, mappings and strategies is warranted. In conclusion, innovative sustainable urban food policies can only achieve success if decision-makers comprehend and acknowledge the crosscutting and long-term nature of food systems. 
I especially thank Robert A. Huber, Regula Hess, Alexandra Botzat, Alexander Schrode, Timo Eckhardt, Gerhard Hammerschmid, Sarah Gang, and Brillé Anderson for their valuable feedback.

\section{References}

Aberbach, J., B. Rockman. 2002. Conducting and coding elite interviews. Political Science and Politics 35/4: 673-676.

Bajželj, B. et al. 2014. Importance of food-demand management for climate mitigation. Nature Climate Change 4/10: 924-929.

Barling, D. et al. 2013. Revaluing public sector food procurement in Europe: An action plan for sustainability. Wageningen: Wageningen University.

Beach, D., R. B. Pedersen. 2013. Process-tracing methods: Foundations and guidelines. Michigan, IL: University of Michigan Press.

Bernauer, T. 2013. Climate change politics. Annual Review of Political Science 16: $421-448$.

Boston, J. 2016. Governing for the future: Designing democratic institutions for a better tomorrow. Bingley, UK: Emerald Group.

Bulkeley, H. 2010. Cities and the governing of climate change. Annual Review of Environment and Resources 35: 229-253

Carey, J. 2013. Urban and community food strategies: The case of Bristol. International Planning Studies 18/1:111-128.

Fesenfeld, L. P. 2012. Towards long-term oriented and sustainable decisions in EU agricultural politics: A deliberative model. B.A. Thesis, Maastricht University.

Franzen, A., D. Vogl. 2013. Two decades of measuring environmental attitudes: A comparative analysis of 33 countries. Global Environmental Change 23/5: 1001-1008.

Gentner, D., A. L. Stevens. 2014. Mental models. Sussex: Psychology.

George, A. L., A. Bennett. 2005. Case studies and theory development in the social sciences. Cambridge, MA: MIT.

Haas, P. 1992. Introduction: Epistemic communities and international policy coordination. International Organization 46: 1-35.

Hovi, J., D. F. Sprinz, A. Underdal. 2009. Implementing long-term climate policy: Time inconsistency, domestic politics, international anarchy. Global Environmental Politics 9: 20-39.

Hunter, L. M., A. Hatch, A. Johnson. 2004. Cross-national gender variation in environmental behaviors. Social Science Quarterly 85/3: 677-694.

Jacobs, A. M. 2011. Governing for the long term: Democracy and the politics of investment. Cambridge, UK: Cambridge University Press.

Jacobs, A. M. 2016. Policy making for the long term in advanced democracies. Annual Review of Political Science 19/1: 433-454.

Jacobs, A. M., J.S. Matthews. 2012. Why do citizens discount the future? Public opinion and the timing of policy consequences. British Journal of Political Science 42/4: 903-935.

Jacobs, A. M., J.S. Matthews. 2015. Policy attitudes in institutional context: Rules, uncertainty, and the mass politics of public investment. American Journal of Political Science 1: 1-14

Kahneman, D., A. Tversky. 1984. Choices, values, and frames. American Psychologist 39/4: 341.

Kayser, M. A., R. Lindstädt. 2015. A cross-national measure of electoral competitiveness. Political Analysis 23/2: 242-253.

Kydland, F.E., E. C. Prescott. 1977. Rules rather than discretion: The inconsistency of optimal pans. Journal of Political Economy 85/3: 473-491.

Lijphart, A. 2012. Patterns of democracy: Government forms and performance in thirty-six countries. New Haven, CT: Yale University Press.

Lohrberg, F. et al. 2015. Urban agriculture europe. Berlin: Jovis.

MacKenzie, M. K. 2016. Institutional design and sources of short-termism. In: Political institutions for future generations. Edited by A. Gosseries, I. González-Ricoy. Oxford, UK: Oxford University Press.

Mansfield, B., W. Mendes. 2013. Municipal food strategies and integrated approaches to urban agriculture: Exploring three cases from the global north. International Planning Studies 18/1: 37-60.

McGuire, M., R. Agranoff. 2011. The limitations of public management networks. Public Administration 89/2: 265-284.

Milkman, K. L. et al. 2012. Policy bundling to overcome loss aversion: A method for improving legislative outcomes. Organizational Behavior and Human Decision Processes 117/1: 158-167.
Moragues, A. et al. 2013. Urban food strategies: The rough guide to sustainable food systems. www.foodlinkscommunity.net/fileadmin/documents_ organicresearch/foodlinks/publications/Urban_food_strategies.pdf (accessed September 7, 2014).

Morgan, K. 2015. Nourishing the city: The rise of the urban food question in the global north. Urban Studies 52/8: 1379-1394.

Moschitz, H., C. Kueffer. 2016. Urban agriculture: Passing fad or new prospects for agriculture and cities? GAIA 25/2: 128-130.

Moschitz, H., B. Oehen, R. Rossier, A. Wirz. 2015. Regionaler Konsum in Freiburg. http://orgprints.org/30031/1/moschitz-etal-2015-Regionaler KonsumFreiburg_Schlussbericht.pdf (accessed September 14, 2014).

Nordhaus, W. 1975. The political business cycle. Review of Economic Studies 42/2: 169-190.

Przeworski, A., H. Teune. 1970. The logic of comparative social inquiry. New York: John Wiley \& Sons.

Rhodes, R. A. W. 2006. Policy network analysis. In: The Oxford handbook of public policy. Edited by R. E. Goodin. Oxford, UK: Oxford University Press. 423-445.

Roehl, R., M. Fülles. 2012. Bewertung der Preisgestaltung von Lebensmitteln unterschiedlicher Qualitätsstandards im Rahmen der CookaChill-Verpflegung. https://www.muenchen.de/rathaus/.../averdis_gutachten-1.pdf (accessed Oktober 14, 2014).

Sabatier, P. A. 1987. Knowledge, policy-oriented learning, and policy change: An advocacy coalition framework. Science Communication 8/4: 649-692.

Schaffer, L. M. 2011. Voluntary climate change initiatives in the US: Analyzing participation in space and time. Dissertation, ETH Zurich.

Schmitter, P. C., G. Lehmbruch. 1982. Patterns of corporatist policy-making. Washington, D. C.: Sage.

Scruggs, L. 2001. Is there really a link between neo-corporatism and environmental performance? Updated evidence and new data for the 1980s and 1990s. British Journal of Political Science 31/4: 686-692.

Stadt München. 2013. Bio und Billig - Kein Widerspruch oder Wie kann der Anteil ökologischer, regionaler und fair gehandelter produkte in städtischen Kantinen zu sozialen Preisen gesteigert werden. https://www.ris-muenchen.de/ RII/RII/ris_vorlagen_dokumente.jsp?risid=3017166 (accessed Oktober 23, 2014).

Sunstein, C. 2014. Why nudge: The politics of libertarian paternalism. New Haven, CT: Yale University Press.

Tsebelis, G. 2002. Veto players: How political institutions work. Princeton, NJ: Princeton University Press.

UN (United Nations). 2014. World urbanization prospects, the 2014 revision. https://esa.un.org/unpd/wup (accessed March 23, 2015).

Weaver, R. K. 1986. The politics of blame avoidance. Journal of Public Policy 6/4: 371-398

Wegrich, K., M. Lodge. 2014. The problem-solving capacity of the modern state: Governance challenges and administrative capacities. Oxford, UK: Oxford University Press.

Wellesley, L., C. Happer, A. Froggatt. 2015. Changing climate, changing diets: Pathways to lower meat consumption. Chatham House Report. London: Chatham House.

Submitted March 3, 2016; revised version accepted November 22, 2016

Lukas P. Fesenfeld

Born 1988 in Essen, Germany. 2012 B. A., 2015 Master of Public Policy (MPP/M.Sc.), Hertie School of Governance, Berlin, Germany. Since April 2016 PhD student at ETH Zurich, Switzerland. Co-founder and president of the nonprofit organisation NAHhaft - Institute for sustainable food strategies, Berlin. Research interests: nexus of food and climate/environmental politics, long-term governance, political economy, political psychology. 